\title{
Transfusional audit in a Hospital of High Specialty, Retrospective analysis of 12 months
}

\author{
Miguel Ángel Cano-Palmeros ${ }^{*}$, Jorge Castañón-González², Miguel Ángel Cano-Quevedo, \\ Dora Stephanie Morales-Uchino ${ }^{3}$, Araceli Benavides-González', Alejandro Espinosa-Kurit and \\ Diana Elvia Ruiz-Moreno ${ }^{4}$ \\ ${ }^{1}$ Department of Transfusion, High Specialty Hospital, Veracruz; ${ }^{2}$ Intensive Care Unit, Hospital Juárez, Ciudad de México; ${ }^{3} H i g h$ Specialty Hospital \\ of Veracruz; ${ }^{4}$ Faculty of Medicine, Universidad Cristóbal Colón Veracruz, Mexico
}

\begin{abstract}
Human blood is the only source of red blood cells, platelets and plasma, and includes the clotting factors. Transfusion of concentrated erythrocyte and blood products is a simple form of organ transplant, the benefits of blood transfusion are real, and the life of the patients depends on how is used. Objective: to know the transfusion adherence to the recommendations in the Hospital of High Specialty of Veracruz, Methods: For a period of 12 months an audit took place in the Transfusion Service of the Hospital of High Specialty of Veracruz, México, on a basis of 3168 requests for transfusion from which 2314 corresponded to erythrocyte concentrate, 220 to platelet concentrate, 493 to fresh frozen plasma and 41 to cryoprecipitate. Results and conclusions: An analysis of concordance was made with the different established regulations for a right indication and the results showed that 2171 (67.26\%) were appropriate and 1037 were inadequate, which means that the lack of academic training in medicine transfusional affects the risk for patients and cost for Health Institutions.
\end{abstract}

KEY WORDS: Transfusion. Audit took. Erythrocyte concentrate. Platelet concentrate.

\section{Introduction}

Human blood is the only source of red blood cells, platelets and plasma, and it includes the coagulation factors. Transfusion is a simple form of organ transplantation, since it is transferred from a donor to a patient to temporally correct a deficiency or functional alteration'.

Blood transfusion benefits are real, and patients' life can depend on its use; however, it is not free of risks and, although it has acquired great development and safety, providing a blood component with zero-risk is still not possible? ${ }^{2}$.
Blood transfusion most widely known include non-hemolytic febrile reactions, immune hemolysis, graft versus host disease, immunomodulation and infections, such as the one produced by the human immunodeficiency virus, malaria end $B$ and $C$ hepatitis ${ }^{3,4}$.

The Mexican Official Standard NOM 253-SSA-2012 "For the disposal of human blood and its components with therapeutic purposes" establishes that the doctor is responsible to indicate a transfusion, which makes it imperative for the healthcare to broaden his/her knowledge on specific indications, risks, benefits and alternatives. A deficient evaluation that leads to an

\author{
Correspondence: \\ Miguel Ángel Cano-Palmeros \\ Servicio de Transfusión \\ Hospital de Alta Especialidad de Veracruz \\ Av. 20 de noviembre 1074 \\ Col. Centro \\ C.P.91900, Veracruz, México \\ E-mail: mangelcanop@gmail.com
}

Date of reception: 09-07-2016

Date of acceptance: 11-07-2016

DOI://dx.doi.org/10.24875/GMM.M18000077
Gac Med Mex. 2017;153:692-695

Contents available at PubMed www.gacetamedicademexico.com 
Table 1. Indications for blood components transfusion according to two transfusion guidelines

\begin{tabular}{|c|c|}
\hline Blood component & Transfusion recommendations of the Mexican Association of Transfusional Medicine \\
\hline $\mathrm{d} b$ & $\begin{array}{l}\text { Anemia with signs and symptoms of tissue hypoxia and not amenable to be treated by other means. } \\
\text { Preoperative hemoglobin }<8 \mathrm{~g} / \mathrm{dL} \text { in patients that are to undergo surgical procedures with high risk for bleeding, } \\
\text { when anemia has no specific treatment and the intervention is not deferrable. The recommended dose is } 1-2 \\
\text { units every } 24 \text { hours, which shall be repeated according to the patient clinical condition. }\end{array}$ \\
\hline Platelet concentrate & $\begin{array}{l}\text { Platelet concentrates prophylactic transfusion should be considered in stable patients under chemotherapy and } \\
\text { myelosuppression with platelet counts }<10,000 / \mu \mathrm{L} \text { and in patients who are to undergo invasive procedures or } \\
\text { surgery with platelet counts }<50,000 / \mu \mathrm{L} \text {. } \\
\text { It should also be considered in those patients with fever or infection with platelet counts }<20,000 / \mu \mathrm{L} \text {. The } \\
\text { recommended dose in an adult is } 1 \text { platelet concentrate unit for every } 10 \mathrm{~kg} \text { weight. }\end{array}$ \\
\hline Fresh frozen plasma & $\begin{array}{l}\text { Transfusing fresh frozen plasma is recommended for the correction of a coagulation factor (factors II, V, VII, } \\
\mathrm{IX}, \mathrm{X} \text { and XII) deficiency and natural anticoagulant (antithrombin II, C-protein and S-protein replacement. To } \\
\text { immediately revert the bleeding-associated effect of anticoagulants, or when an emergency invasive or surgical } \\
\text { procedure is required. Its use may be conditioned in massive transfusion, liver disease, occasionally to provide } \\
\text { other plasma constituents (C-1 esterase inhibitor in hereditary angioneurotic edema). Its use is recommended in } \\
\text { any patient with a coagulation index }>1.5 \text { that is to undergo a surgical procedure. }\end{array}$ \\
\hline Cryoprecipitate & $\begin{array}{l}\text { Hemophilia A treatment when factor VIII concentrate is not available. Type } 1,2 \text { and } 3 \text { von Willebrand disease in } \\
\text { the absence of desmopressin (DDAVP), except for type } 2 \mathrm{~b} \text {. Dysfibrinogenemia. Factor XIII deficiency. Uremia } \\
\text { and bleeding, or in the absence of desmopressin (DDAVP). Replacement with cryoprecipitate should be made } \\
\text { taking into consideration that each bag contains an average of } 100 \mathrm{IU} \text { of factor VIII. }\end{array}$ \\
\hline
\end{tabular}

unnecessary transfusion can have effects on patient health and safety ${ }^{5}$.

There have been reports indicating that there is an increase in the number of unnecessary transfusions, and various strategies have therefore been implemented, such as transfusional audits, which can be retrospective, concurrent and prospective, and that have the purpose transfusion control. Diverse institutions have published guidelines to improve transfusional practice and minimize the risks of adverse effects. In Mexico, as in other countries, the transfusion of blood products has increased; thus, recommendations for blood and blood products transfusional therapy have been implemented with the purpose to provide the medical population with evidence-based knowledge that leads to the correct use of this type of intervention ${ }^{6-11,13,14}$.

In Mexico, $4.8 \%$ cases of AIDS are secondary to a blood transfusion, including hemophilic patients. Post-transfusion viral hepatitis is the most common complication and causes 80 to $90 \%$ of cases of hepatitis $\mathrm{C}$. Therefore, monitoring of transfusion therapeutic and adverse effects is an important aspect in the review on the use of blood?

When the use of blood components is limited, the blood bank operating costs are reduced and its personnel working time is improved; at hospitalization, it decreases the use of material, and the cost generated by the treatment of complications is averted; the patients are favored because they receive an optimal treatment at minimum risk and lower cost and, finally, physicians also benefit because they prescribe a treatment that adheres to established guidelines, which reduces their vulnerability in case of medical-legal problems ${ }^{8-11}$.

The purpose of this work is to know transfusion adherence to current recommendations at the High Specialty Hospital of Veracruz.

\section{Method}

This was a quantitative, retrospective study that consisted in the review of blood transfusion request recorded in the database about blood and blood components deposits and withdrawals at the Regional High Specialty Hospital blood bank for the management of patients with deficiency of these products. The requests filed from December 1, 2013 to November 30, 2014 were reviewed, with a sample size calculated based on total requests captured over one year. The study included all those transfusion requests that had the following data: patient ID, requested blood component and number of transfused units, clinical diagnosis, and the following paraclinical studies: hemoglobin, hematocrit, platelet count, prothrombin time and activated partial thromboplastin time. The transfusion indication of each one of the recorded requests was individually analyzed, taking the patients' laboratory analyses results into account, with the transfusion being considered to be adequate or inadequate according to the Mexican Association of Transfusional Medicine transfusion recommendations 
Table 2. Proportion of administered blood components

\begin{tabular}{lccr}
\hline Blood component & & \multicolumn{2}{c}{ Transfusion indication } \\
\cline { 3 - 4 } & & Adequate & Inadequate \\
\hline Red blood cell concentrate & 2414 & $1550(64.21 \%)$ & $864(35.79 \%)$ \\
Platelet concentrate & 220 & $86(39.09 \%)$ & $134(60.91 \%)$ \\
Fresh frozen plasma & 493 & $493(100 \%)$ & 0 \\
Cryoprecipitate & 41 & $2(4.88 \%)$ & $39(95.12 \%)$ \\
Total & 3168 & $2131(67.26 \%)$ & $1037(32.73 \%)$ \\
\hline
\end{tabular}

(Table 1). The data analysis was performed using descriptive statistics.

Out of 3168 analyzed transfusion requests, 2414 corresponded to red blood cell (RBC) concentrate, 220 to platelet concentrate, 493 to fresh frozen plasma and 41 to cryoprecipitate. Of total transfusion requests, 2131 (67.26\%) were adequate and 1037 (32.73\%) were inadequate. According to the requested blood components, 1550 (64.21\%) RBC concentrates were adequate and 864 (35.79\%) were inadequate; all 493 (100\%) fresh frozen plasmas were adequately indicated; and of total cryoprecipitate transfusions, $39(95.12 \%)$ were inadequate and only $2(4.88 \%)$ were adequate (Table 2$)$.

\section{Discussion}

This translates the lack of knowledge and adherence to traditional guidelines and, therefore, the risk represented by blood components transfusion is increased, as well as the squander of resources. All this forces for a basic transfusional medicine program to be considered in medicine faculties, as well as for resident trainees of all specialties.

The analysis of results reported that in $67.26 \%$ of cases the transfusion indication was adequate and that in $32.73 \%$ it was inadequate. By components, $60.91 \%$ of platelet concentrate and $95.12 \%$ of cryoprecipitate transfusions were inadequately indicated. The literature shows that up to $26 \%$ of platelet concentrates can be inadequate. As for platelet concentrate transfusion indications, one of the most relevant is that patients with platelet counts below $5000 / \mathrm{mm}^{3}$ and those with values ranging from 5000 to $10,000 / \mathrm{mm}^{3}$ have high probability of spontaneous hemorrhage. As for the use of cryoprecipitate, patients may exhibit diffuse microvascular bleeding and fibrinogen at values $<100 \mathrm{mg} / \mathrm{dL}$. The results obtained at the High Specialty Hospital of Veracruz as regards RBC concentrate indications are higher than those from the audit carried out by the National Center of Transfusion, which is quite favoring, since this is the most widely transfused blood concentrate.

Owing to the lack of clinical criteria on when to start transfusional therapy, a good strategy is a hemoglobin threshold value of $6 \mathrm{mg} / \mathrm{dL}$; otherwise, the best is to monitor each patient in order to prevent blood loss until blood components replacement is possible, and it should be adequate in order to avoid possible side effects and economic losses, and in order for it to result as beneficial as possible for the patient. The performance of a constant monitoring of each transfusion request, the development of guidelines for therapy with blood components, internal audits and implementation of a basic transfusional medicine program would reduce the percentages of inadequate transfusion indications, and would prevent the occurrence of adverse reactions secondary to clinical practice and the costs it entails would proportionally decrease.

\section{Conclusion}

In our hospital, as a result of the results found, carrying out a continuing medical education program for the use of blood and blood components was jointly agreed by our Committee of Transfusional Medicine and the Teaching Department. Working hand in hand with the Blood Surveillance Committee will continue, which will give a follow-up to the results that are to be obtained once the first training course is concluded.

We encourage all hospitals to perform periodical audits to identify irregularities in the basic and routine practice of transfusional medicine.

\section{References}

1. Pliego Reyes C, Flores Alcantar G. Evolución de la transfusión sanguínea. Revista de la Facultad de Medicina de la UNAM. 2012;55:35-42.

2. Barba Evia J, Suárez Monterrosa E. Transfusión de paquete globular. Del beneficio clínico real a la inadecuada prescripción. Rev Latinoam Patol Clin Med Lab. 2015;62:46-54 
3. Flores Paredes W. Prescripción inadecuada de transfusión sanguínea en un hospital de referencia de Lima, Perú 2011. Rev Perú Med Exp Salud Pública. 2011;28:617-22.

4. Corbalá Fuentes C, Navarro Jaramillo F, Aguilar Solano A, et al. Análisis del uso clínico de la hemotransfusión. Rev Mex Patol Clin. 2003:50:104-8.

5. Tena Tamayo C, Sánchez González J. La transfusión sanguínea y los derechos del paciente. Revista CONAMED. 2015;10:20-6.

6. Juárez Rangel E, Vite Casanova M, Marin y López R, et al. Auditoría transfusional retrospectiva en el Centro Nacional de Transfusión Sanguínea. Revista de Investigación Clínica. 2004;56:38-42.

7. Barba Evia J. Transfusión de sangre y sus componentes: riesgos, beneficios e indicaciones. Rev Mex Patol Clin. 2004:51:97-108.

8. Cuevas Cisneros R, Acuña Mamani J, Grajeda Ancca P, et al. Criterios clínicos y laboratoriales usados para indicar paquete globular y plasma fresco congelado en el Hospital de Apoyo Departamental Cusco, 2006.
SITUA. 2006;15:14-22.

9. Malagón Martínez A, et al. Guía para el uso clínico de sangre. 3. ${ }^{\text {a }}$ ed. México: Secretaría de Salud; 2007.

10. Kaufman RM, Djulbegovic B, Gernsheimer T, et al. Platelet transfusion: a clinical practice guideline from the AABB. Ann Intern Med. 2015;162:205-13.

11. Carson JL, Grossman BJ, Kleinman S, et al. Red blood cell transfusion: a clinical practice guideline from the AABB. Ann Intern Med. 2012; 157:49-58.

12. Roback JD, Caldwell S, Carson J, et al. Evidence-based practice guidelines for plasma transfusion. Transfusion. 2010;50:1227-39.

13. Malagón A. Recomendaciones para la terapia transfusional de sangre y sus componentes. Gac Med Mex. 2002;138(Supl 1):S35-7.

14. Brecher M. Techincal manual. $14^{\text {th }}$ ed. American Association of Blood Banks; 2013. p. 451-80. 